\title{
A BIOLÓGIAI TERÁPIA EGÉSZSÉGGAZDASÁGI VONATKOZÁSAI
}

\section{HEALTH ECONOMIC ASPECTS OF BIOLOGICAL THERAPIES}

\author{
Péntek Márta', Gulácsi László \\ 'PhD, egyetemi tanár, Budapesti Corvinus Egyetem Egészségügyi Közgazdaságtan Tanszék, Budapest \\ marta.pentek@uni-corvinus.hu \\ ªz MTA doktora, tanszékvezető egyetemi tanár, Budapesti Corvinus Egyetem Egészségügyi Közgazdaságtan Tanszék, Budapest \\ laszlo.gulacsi@uni-corvinus.hu
}

\section{ÖSSZEFOGLALÁS}

\begin{abstract}
A költséges biológiai gyógyszerek megjelenésével egyre fontosabbá váltak azok az egészségügyi közgazdaságtani kutatások, amelyek ezen terápiák esetén a rendelkezésre álló erőforrások optimális elosztásával foglalkoznak. A biológiai terápiák hatékonysága miatt előtérbe kerültek az életminőségre és a munkaképességre gyakorolt hatások, a társadalmi szinten elérhető egészségnyereség kérdései, a megosztott döntéshozatal, a betegek egészségi állapotukkal kapcsolatos elgondolásai és elvárásai. A biológiai gyógyszerek magas költsége és az egyre több beteg folyamatos kezelése miatt a finanszírozási szempontok a mindennapi betegellátás, az orvosi döntések szerves részévé váltak. A biológiai terápiához való hozzájutás húsz évvel az első szer regisztrációja után is jelentős eltéréseket mutat hasonló gazdasági helyzetű országok között és különböző diagnózisok esetében az egyes országokon belül.

A biohasonlók megjelenése, az alacsonyabb gyógyszerár miatt, jelentősen javítja a költséghatékonyságot, és lehetővé teszi az új originális biológiai termékek szélesebb körű felhasználását. Az egyre bővülő biológiai terápiás palettának köszönhetően ma már nem egyes kiválasztott szerek költséghatékonyságát, hanem terápiás stratégiák, terápiás szekvenciák költséghatékonyságát célszerű összehasonlítani ahhoz, hogy a legköltséghatékonyabbat megtaláljuk. A biohasonlók mellett is igen magas összegek szükségesek az egy jó minőségű életév (1 QALY) nyereség eléréséhez, és az új, költséges originális termékek csak jól megválasztott terápiás stratégiák részeként válhatnak elérhetővé a betegek számára. Az elkövetkező években a biológiai terápiás lehetőségek további bővülése várható.
\end{abstract}

\section{ABSTRACT}

Health economic evaluations, dealing with the optimal distribution of available resources, have become increasingly important in clinical areas where biologic treatments were developed and registered. Due to the high efficacy of biologicals, effects on health-related quality of life, productivity and societal health gains came into focus, as well as the need for shared decision making considering patients' ideas and subjective health expectations. Because of the high cost of biological drugs and continuous treatment of more and more patients, financing considerations have become an integral part of everyday clinical practice and medical decision making. Now- 
adays, 20 years after the registration of the first biologic drug, access to biological therapy still shows significant differences between countries with comparable economic conditions, and also between different diagnoses within a given country.

The emergence of biosimilars at lower prices significantly improves the cost-effectiveness and allows also a wider use of new original biologics. The biological drug palette is expanding hence not single therapies but therapeutic (drug) sequences should be compared in order to find the most cost-effective strategy. In the era of biosimilars, still high amounts are needed to achieve a good-quality life-year (1 QALY) gain, and new, expensive original products can only be available as part of well-chosen therapeutic strategies. In the coming years, registration of further biological therapies is expected.

Kulcsszavak: biológiai gyógyszerek, bioszimiláris gyógyszerek, egészségügyi közgazdaságtan, egészséggel összefüggő életminőség, költséghatékonyság, költségvetési hatáselemzés

Keywords: biologic drugs, biosimilar drugs, health economics, health-related quality of life, cost-effectiveness, budget impact analysis

\section{BIOLÓGIAI GYÓGYSZEREK, EGÉSZSÉGPOLITIKA, NÉPEGÉSZSÉGÜGY - MI IS VÁLTOZIK?}

A krónikus immunológiai megbetegedések területén az elmúlt húsz év során jelentős változásoknak lehettünk tanúi. Egyrészt a biológiai szerek hatására megváltoztak a terápiás célok: ma a cél a teljes remisszió elérése, a károsodások megelőzése. Olyan betegek kezelése is lehetővé vált, akik számára azelőtt nem állt rendelkezésre megfelelő terápia. Másrészt a terápia eredménye olyan területeken is jelentkezik, amelyekre korábban, terápiás lehetőség hiányában, kevesebb figyelem irányult, ide tartoznak az életminőség, munkaképesség és a társadalmi hatás. Kiemelten fontossá vált a betegek bevonása a döntéshozatalba, elötérbe kerültek a betegek véleményén alapuló egészségi állapot- és életminőség-mércék, a betegek egészségi állapotukkal kapcsolatos elgondolásai és elvárásai (Péntek et al., 2014a; Péntek et al., 2014b).

Nemcsak az átlagpopuláció, hanem az érintett betegek várható élettartama is növekszik, így folyamatosan nő ezen betegségek prevalenciája. A biológiai terápiák magas költsége és az egyre több beteg egyre hosszabb távon, sok esetben élethosszon történő, folyamatos kezelése miatt a finanszírozási szempontok is a mindennapi betegellátás, az orvosi döntések szerves részévé váltak. Azonban a leghatékonyabb biológiai gyógyszer is csak akkor hat, ha a betegek megfelelö finanszírozással hozzá is jutnak. Ha kevesebb beteget kezelnek biológiai terápiával, mint akinek abból haszna lehetne, akkor a társadalmi szinten elérhető egészségnyereség alacsonyabb, mint lehetne. A finanszírozási döntések határozzák meg az egyén és a társadalom szintjén elérhető egészség-haszon nagyságát. 
Van egy nagyon fontos további szempont is. A hozzáférés különbsége miatti méltánytalanság (inequity) a nagyon hatékony terápiák esetén sokkal jelentősebb, mint az korábban volt, hiszen nagyon nagy az életminőség-különbség két azonos súlyosságú páciens között, attól függően, hogy megkapja-e a biológiai terápiát vagy sem. A hozzáférési különbség (1. ábra) pedig még a hasonló vagy egymással összemérhető egy före eső GDP-jü országokban is jelentős (Gulácsi et al., 2016; Gulácsi et al., 2017a; Péntek et al., 2014c; Péntek et al., 2017a; Rencz et al., 2015).

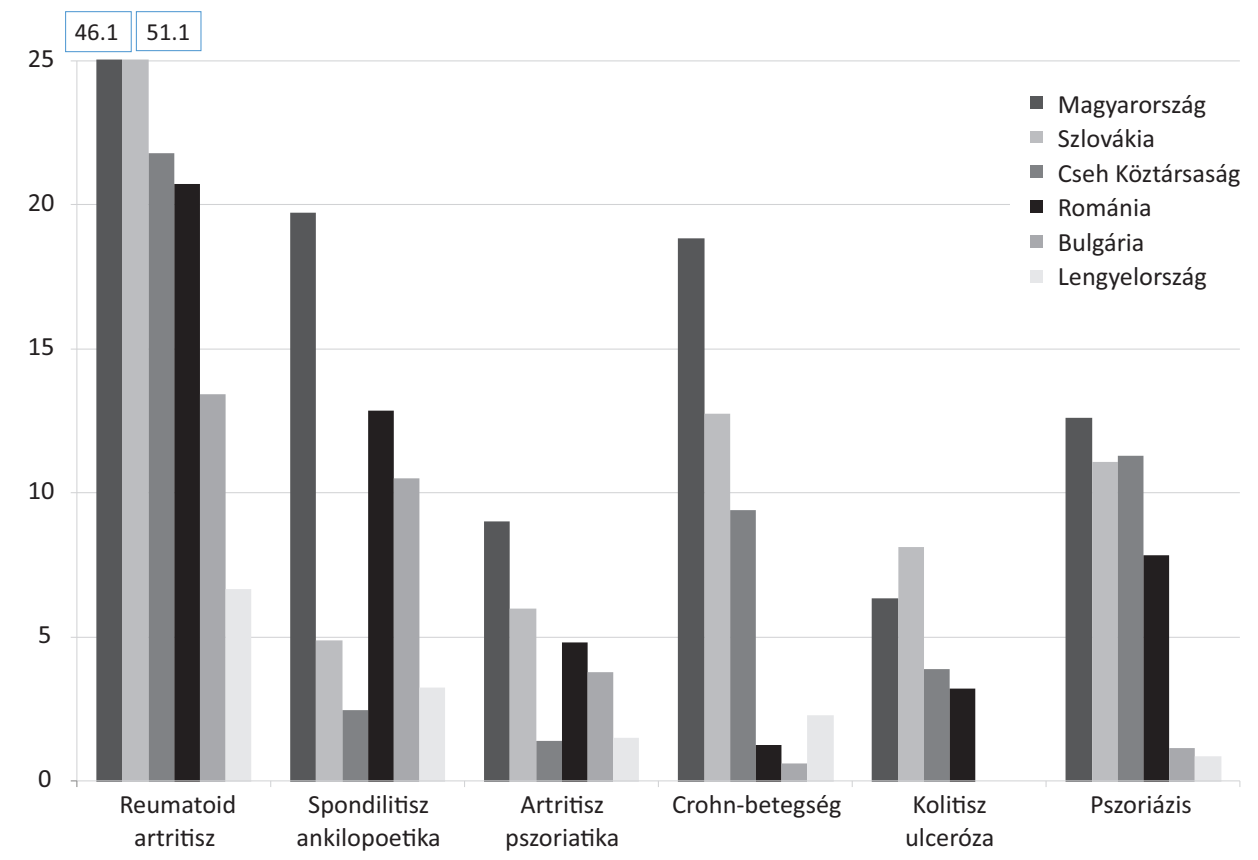

1. ábra. Biológiai terápiákhoz való hozzáférés reumatoid artritisz, spondilitisz ankilopoetika, artritisz pszoriatika, Crohn-betegség, kolitisz ulceróza és pszoriázis esetén (100 000 lakosra jutó biológiai gyógyszerrel kezelt betegek száma) (saját szerkesztés, Gulácsi et al., 2016)

A költséges biológiai gyógyszerek megjelenésével egyre fontosabbá váltak azok az egészségügyi közgazdaságtani kutatások, amelyek ezen terápiák esetén a rendelkezésre álló erőforrások optimális elosztásával foglalkoznak. A betegség-költség vizsgálatok azt mutatják meg, hogy az adott betegség esetén mekkora a betegségteher, és ez mely területeken jelentkezik? Melyek a legjelentősebb költségtényezők, és ezek hogyan változnak a betegség lefolyása során? A betegség-költség azt is mutatja, hogy a betegség eliminálásával mekkora lenne a megtakarítás.

A költséghatékonysági elemzések a terápiákkal kapcsolatos döntéshozatalt segítik elő. Azt mutatják meg, hogy az új terápiával elérhető többlet-egészségnyereség milyen többletköltség felhasználásával érhető el. A biológiai gyógyszerekkel 
kezelhető betegségekben azonban kevés adat állt rendelkezésre. Így a biológiai gyógyszerek egészség-gazdaságtani kutatásai az első években a betegséggel járó költségek felmérését célozták meg. Ezen belül is kiemelten vizsgálták a munkából való kiesés (betegállomány, rokkantnyugdíj) vagy csökkent termelékenység miatti költségeket, valamint a családra háruló gondozási terheket.

A krónikus immunológiai megbetegedések esetén a finanszírozó számára jelentkező direkt költségek a biológiai terápiákat megelőző időszakban az összköltség 30-40\%-át tették ki, a költségek nagyobb része az indirekt költségek kategóriájába esik. A finanszírozói adatbázisok tehát a betegségek tényleges súlyára vonatkozó és a megfelelő egészségpolitikai döntések megalapozásához szükséges adatokat még a legjobb esetben is csak részben tartalmazzák.

A QALY (good-quality life-year), a jó minőségü életév az az egészségügyi közgazdaságtanban széles körben használatos kimenet, amelynek segítségével a különböző betegségek okozta egészségveszteség és a biológiai terápiákkal elérhető egészségnyereség összehasonlíthatóvá válik, és így a költség/QALY alapvető számítás lett a finanszírozói döntéshozatalban. A költségvetési hatás elemzése minden európai országban jogszabályok által elöírt követelmény mindazon gyógyszerek esetén, amelyeket a forgalmazó társadalombiztosítási finanszírozás igénybevételével kíván elérhetővé tenni. Ezek az adatok azonban az országok egy része esetén nem állnak rendelkezésre. Ezek jelentős részben hozzájárultak ahhoz, hogy az első biológiai gyógyszerek regisztrációja és társadalombiztosítási befogadása között hazánkban, és a közép- és kelet-európai országokban jellemzően hat-tíz év telt el, míg a nyugat-európai országokban gyorsabban és szélesebb körben terjedtek el ezek a kezelések. A biológiai terápiához való hozzájutás azonban húsz évvel az első szer regisztrációja után is jelentős eltéréseket mutat, akár az egyes országokon belül is, ami új társadalmi, egészség-gazdaságtani kérdéseket vet fel.

\section{JELENTŐS HOZZÁFÉRÉSI EGYENLŐTLENSÉGEK}

A krónikus immunológiai betegségek esetén a biológiai terápiákhoz való hozzáférési különbségek igen jelentősek. Crohn-betegségben és kolitisz ulcerózában (gyulladásos bélbetegségek, IBD) egy, a közép- és kelet-európai országokban zajlott felmérés eredményei azt mutatják, hogy 96-szoros eltérés is előfordul az országok között. Lengyelországban például tízszer kisebb az esélye annak, hogy egy IBD-beteg biológiai terápiára kerüljön, mint Magyarországon (Rencz et al., 2015). Egy 2017-es, szintén Crohn-betegségben a biológiai terápiához való hozzáférést vizsgáló tanulmány pedig azt mutatja, hogy a magas GDP-vel rendelkező országok között is jelentősek az eltérések. A hozzáférés a legmagasabb Svédországban (54 beteg/100 000 lakos), a legalacsonyabb Lengyelországban (2 beteg/100 000 lakos), Romániában (1 beteg/ 100000 lakos) és Lettországban ( $<1$ beteg/100 000 lakos) (Péntek et al., 2017a). 
Hasonló hozzáférési eltérések láthatók a pszoriázis esetén is a biológiai terápiák vonatkozásában. Egy közép-kelet-európai országokban zajlott felmérés azt mutatja, hogy az országok közötti hozzáférési különbség tizenötszörös. A reumatológiai betegségek terén is jelentős különbséget látunk az országok és diagnózisok közötti összehasonlítás során (Gulácsi et al., 2016).

Hazánkban a hozzáférés a vizsgált országok felső szegmensében található, hasonló, illetve jobb, mint a Cseh Köztársaságban és Szlovákiában, és jelentősen kedvezőbb, mint Lengyelországban, illetve a többi vizsgált országban. Eredményeink azt is nagyon jól mutatják, hogy az egyes országok egy före eső GDP-jétől nem tekinthetünk el, az egy före eső GDP azonban nem minden esetben magyarázza a hozzáférési különbségeket. Lengyelországban például közel azonos az egy före eső GDP, mint hazánkban, azonban arányaiban sokkal kevesebb beteget kezelnek a nagyon hatékony és költséges biológiai terápiákkal.

\section{BIOHASONLÓK, KÖLTSÉGHATÉKONYSÁG, TERÁPIÁS SZEKVENCIÁK}

A biohasonló szerek piacra kerülése jelentősen javíthatja a modern, nagyon hatékony terápiákhoz való hozzáférést. A hasonló biológiai gyógyszer olyan szer, amelyet úgy fejlesztettek ki, hogy hasonló legyen egy már meglévő biológiai gyógyszerhez (referencia-gyógyszer). A hasonló biológiai gyógyszer és referencia-gyógyszerének hatóanyaga lényegében ugyanaz a biológiai anyag, bár összetett jellegük és a gyártási módszerük miatt lehetnek köztük kisebb különbségek.

Ezeknek a szereknek a klinikai hatásossága és biztonságossága nem különbözik szignifikánsan az originátor termékekétől (Baji et al., 2014). Az árakra gyakorolt hatás kettős, egyrészt az esetek jelentős részében a biohasonlók ára kedvezőbb, mint az originátor termékeké, másrészt árversenyre kényszerítik az originátor termékek forgalmazóit. Alkalmazásuk jelentős költségmegtakarítást tesz lehetővé, amely megtakarítást új betegek terápiájára fordítva társadalmi szinten igen jelentős többlet-egészségnyereség érhető el (Brodszky et al., 2016; Gulácsi et al., 2015; Gulácsi et al., 2017b; Péntek et al., 2017b). A biohasonlók alkalmazását az orvosok is támogatják, amennyiben a megtakarítás legalább egy részéböl a betegeiknek is többlethasznuk származik (például: több beteg kezelése, könnyebb és gyorsabb terápiára kerülés) (Baji et al., 2016).

A biohasonlók megjelenése jelentősen javítja a költséghatékonyságot, és lehetővé teszi az új originátor biológiai termékek szélesebb körü felhasználását is. A betegek sok esetben nem egy biológiai terápiában részesülnek, hanem, ha az első választott szer hosszabb vagy rövidebb idő után valamilyen ok miatt nem hatásos, akkor a beteg egy második vagy harmadik biológiai gyógyszert kap. Ma már nem egyes kiválasztott szerek költséghatékonyságát, hanem a terápiás stratégiák, terápiás szekvenciák költséghatékonyságát célszerü összehasonlítani ahhoz, hogy a leginkább 
költséghatékonyat megtaláljuk. Példaként említjük a Crohn-betegség biológiai terápiás stratégiáinak összehasonlító költséghatékonysági vizsgálatait. Négy biológiai szert (infliximab, biohasonló-infliximab, adalimumab és vedolizumab) tartalmazó stratégiákat hasonlítottunk össze, mégpedig úgy, hogy vizsgáltuk az egy-, a kettőés a háromelemü biológiai stratégiákat. Az elemzést finanszírozói perspektívából kilenc országban végeztük (Belgium, Franciaország, Németország, Magyarország, Olaszország, Spanyolország, Svédország, Hollandia és az Egyesült Királyság) (Baji et al., 2018; Rencz et al., 2017). A luminális Crohn-betegség esetén a leghatékonyabb egy egyelemü biológiai stratégia a biohasonló-infliximab, amelynek a költséghatékonysága a legalacsonyabb Magyarországon, a legmagasabb Svédországban volt (€35 ezer-€77 ezer/QALY). A leghatékonyabb kételemü biológiai stratégia a biohasonló-infliximab-adalimumab a leginkább költséghatékony Franciaországban és a legkevésbé költséghatékony Németországban volt ( $€ 70$ ezer-€162 ezer/QALY). A leghatékonyabb háromelemü stratégia, biohasonló-infliximab-adalimumab-vedolizumab, a leginkább költséghatékony Hollandiában és a legkevésbé költséghatékony Spanyolországban volt (€206 ezer-€363 ezer/QALY).

Igen magas összegek szükségesek az 1 QALY nyereség eléréséhez, a költséges originátor termékek jól megválasztott terápiás stratégiák részeként válhatnak elérhetővé a betegek számára.

\section{ÖSSZEFOGLALÁS}

Jelenleg kétszáz felé közeledik a nyilvántartott biológiai molekulák száma, és további jelentős növekedés várható. Ezek közül hazánkban több mint harminc szerrel kapcsolatosan adtak már be támogatási kérelmet valamilyen indikációban. Ezeknek a szereknek a költsége olyan magas, hogy csak társadalombiztosítási támogatás mellett válnak hozzáférhetővé a lakosság számára. Reméljük, hogy ezek a szerek, az egészségügyi közgazdaságtan eredményeinek egyre fokozottabb felhasználásának is köszönhetően, egyre hamarabb jutnak el azokhoz a betegekhez, akiknek a terápiából hasznuk származhat.

\section{IRODALOM}

Baji P. - Péntek M. - Czirják L. et al. (2014): Efficacy and Safety of Infliximab-Biosimilar Compared to Other Biological Drugs in Rheumatoid Arthritis: A Mixed Treatment Comparison. The European Journal of Health Economics, 1 (Suppl 1), 53-64. DOI: 10.1007/s10198-014-0594-4, http://unipub.lib.uni-corvinus.hu/1589/

Baji P. - Gulácsi L. - Lovász B. D. et al. (2016): Treatment Preferences of Originator Versus Biosimilar Drugs in Crohn's Disease; Discrete Choice Experiment Among Gastroenterologists. Scandinavian Journal of Gastroenterology, 51, 22-27. DOI: 10.3109/00365521.2015.1054422, https://bit.ly/2XCtWZW 
Baji P. - Gulácsi L. - Brodszky V. - Végh Zs. et al. (2018): Cost-effectiveness of Biological Treatment Sequences for Fistulising Crohn's Disease across Europe. United European Gastroenterology Journal, 6, 310-321. DOI: 10.1177/2050640617708952, https://www.ncbi.nlm.nih.gov/ pmc/articles/PMC5833218/

Brodszky V. - Rencz F. - Péntek M. et al. (2016): A Budget Impact Model for Biosimilar Infliximab in Crohn's Disease in Bulgaria, the Czech Republic, Hungary, Poland, Romania, and Slovakia. Expert Review of Pharmacoeconomics \& Outcomes Research, 16, 119-125. DOI: 10.1586/14737167.2015.1067142, https://bit.ly/2G0jCzX

Gulácsi L. - Brodszky V. - Baji P. et al. (2015): Biosimilars for the Management of Rheumatoid Arthritis: Economic Considerations. Expert Review of Clinical Immunology, 11, (Suppl 1), S43-52. DOI: 10.1586/1744666X.2015.1090313, https://www.tandfonline.com/doi/full/10.1586/ 1744666X.2015.1090313

Gulácsi L. - Rencz F. - Poór Gy. et al. (2016): Patients' Access to Biological Therapy in Chronic Inflammatory Conditions; Per Capita GDP Does Not Explain the Inter-country Differences. Annals of the Rheumatic Diseases, 75, 942-943. DOI: 10.1136/annrheumdis-2015-208741

Gulácsi L. - Péntek M. - Rencz F. et al. (2017a): Biosimilars for the Management of Inflammatory Bowel Diseases: Economic Considerations. Current Medicinal Chemistry, DOI: 10.2174/09298 67324666170406112304, https://bit.ly/2XyMF8m

Gulácsi L. - Brodszky V. - Baji, P. et al. (2017b): The Rituximab Biosimilar CT-P10 in Rheumatology and Cancer: A Budget Impact Analysis in 28 European Countries. Advances in Therapy, 34, 1128-1144. DOI: 10.1007/s12325-017-0522-y, https://link.springer.com/article/10.1007\%2Fs12325-017-0522-y

Péntek M. - Rojkovich B. - Czirják L. et al. (2014a): Acceptability of Less than Perfect Health States in Rheumatoid Arthritis: The Patients' Perspective. The European Journal of Health Economics, 15 (Suppl 1), S73-S82. DOI: 10.1007/s10198-014-0596-2, https://bit.ly/2Jtmo1A

Péntek M. - Gulácsi L. - Rojkovich B. et al. (2014b): Subjective Health Expectations At Biological Therapy Initiation: A Survey of Rheumatoid Arthritis Patients and Rheumatologists. The European Journal of Health Economics, 15,(Suppl 1), S83-S92. DOI: 10.1007/s10198-0140597-1, https://bit.ly/2XLIwgT

Péntek M. - Poór Gy. - Wiland, P. et al. (2014c): Biological Therapy in Inflammatory Rheumatic Diseases: Issues in Central and Eastern European Countries. The European Journal of Health Economics, 15, (Suppl 1), S35-S43. https://bit.ly/32fREcQ

Péntek M. - Lakatos P. L. - Oorsprong, T. et al. (2017a): Access to Biologicals in Crohn's Disease in Ten European Countries. World Journal of Gastroenterology, 23, 6294-6305. DOI: 10.3748/ wjg.v23.i34.6294, https://www.wjgnet.com/1007-9327/full/v23/i34/6294.htm

Péntek M. - Zrubka Z. - Gulácsi L. (2017b): The Economic Impact of Biosimilars on Chronic Immune-mediated Inflammatory Diseases. Current Pharmaceutical Design, 23, 6770-6778. DOI: 10.2174/1381612824666171129193708, https://bit.ly/2XD0EFG

Rencz F. - Péntek M. - Bortlik M. et al. (2015): Biological Therapy in Inflammatory Bowel Diseases: Access in Central and Eastern Europe. World Journal of Gastroenterology, 21, 1728-1737. DOI: 10.3748/wjg.v21.i6.1728, https:/www.ncbi.nlm.nih.gov/pmc/articles/PMC4323448/

Rencz F. - Gulácsi L. - Péntek M. et al. (2017): Cost-utility of Biological Treatment Sequences for Luminal Crohn-s Disease in Europe. Expert Review of Pharmacoeconomics \& Outcomes Research, 17, 597-606. DOI: 10.1080/14737167.2017.1322509, https://bit.ly/2xwXIzI 